\title{
Prolactin and Interleukin-2 Receptors in T Lymphocytes Signal through a MGF-STAT5-Like Transcription Factor
}

\author{
FABRICE GOUILLEUX, DIRK MORITZ, MATJAZ HUMAR, RICHARD MORIGGL, \\ SUSANNE BERCHTOLD, AND BERND GRONFR
}

Institute for Experimental Cancer Research, Tumor Biology Center, D-79106 Freiburg, Germany

\begin{abstract}
The cell surface receptors for PRL and interleukin-2 (IL-2) are structurally distinct, but share regulatory tasks in $\mathrm{T}$ lymphocytes. They can stimulate proliferation and activate transcription of overlapping sets of genes of T cells. PRL and IL-2 receptor activation are both linked to the Jak/Stat (signal transducer and activator of transcription) pathway. We investigated the ability of PRL and IL-2 to activate Stat proteins in different $T$ cell lines. The DNA binding specificities, the reactivities toward Stat-specific antisera, and the mol wt of IL-2- and PRL-induced DNA-binding proteins in Nb2 and Cl96 $\mathrm{T}$ cell lines were investigated. A comparison with the Stat pro-
\end{abstract}

teins induced by interferon- $\gamma$, PRL, and IL-6 in T47D mammary tumor cells was made. We found that these parameters were indistinguishable for one of the PRL- and IL-2-induced factors. A transcription factor closely related to mammary gland factor-Stat5 is rapidly activated upon interaction of IL-2 and PRL with their respective receptors. Activation of a second protein related to Stat1 was also observed. Our results emphasize the role of PRL as a regulator of the immune response and indicate that the Stat factors mammary gland factor-Stat 5 and Stat1 play a role in the regulation of gene expression during T cell development. (Endocrinology 136: 5700-5708, 1995)
$\mathrm{P}$ RL IS A neuroendocrine hormone that controls the proliferation and differentiation of a variety of target cells in vertebrates (1). PRL is best known for its lactotrophic effects in mammary epithelial cells, but it has been recognized that it is also a regulator of the immune system. It affects both humoral and cell-mediated immunity $(2,3)$. PRL receptors are expressed on T and B cells, and PRL is produced not only in the anterior pituitary, but also by lymphoid cells (4-6). In vitro, the growth of T lymphocytes appears to be regulated by PRL in an autocrine manner. PRL is necessary for $\mathrm{T}$ cell proliferation and, in particular, for passage of the cells through the $S$ phase of the cell cycle (7). In vivo, PRL increases antigen-induced peripheral $\mathrm{T}$ cell proliferation (8).

The PRL receptor belongs to the cytokine receptor family. This family includes the receptors for interleukin-2 (IL-2) to IL-7, erythropoietin, granulocyte-macrophage colony-stimulating factor (GM-CSF), GH, and others (9). The members of this family have been subdivided into four groups, based on structural features found in their amino-terminal extracellular ligand-binding domains. None of the cytokine receptors contains cytoplasmic sequence motifs indicative of a protein tyrosine kinase function. However, one of the immediate early biochemical events triggered by PRL binding to its receptor is tyrosine phosphorylation of the receptor and of several cellular proteins (10). In T cells, protein tyrosine kinases, p59fyn and Jak2, as well as a serine-threonine kinase, Raf- 1 , have been found to be associated with and activated by PRL binding to its receptor (10-12).

Downstream effector molecules of the Jak kinases are the Stat (signal transducer and activator of transcription) factors $(13,14)$. Seven members of this family have been identified.

Received June 29, 1995.

Address all correspondence and requests for reprints to: Dr. Bernd Groner, Klinik fur Tumorbiologie, Institute for Experimental Cancer Research, Breisacher Str. 117, D-79106 Freiburg, Germany.
p91-Stat1 constitutes the interferon- $\gamma$ (IFN $\gamma$ )-activated transcription factor (15); p91-Stat1 and p113-Stat2 together with the p48 subunit constitute the IFN $\alpha / \beta$-responsive transcription factor $(16,17)$. APRF-Stat 3 is activated in response to IL-6 $(18,19)$, Stat 4 in response to IL-12 $(20,21)$, mammary gland factor (MGF)-Stat5a in response to PRL (22), and IL-4 Stat6 in response to IL-4 (23). Recently, a Stat5 homolog called Stat $5 b$ has been cloned from mouse hematopoietic cells and mouse mammary cells $(24,25)$. Isoforms of Stat 5 or molecules highly related to Stat 5 have been found in myeloid cell lines $(26,27)$. Stat5-related proteins are activated in response to PRL, IL-3, GM-CSF, IL-5, erythropoietin, GH, and thrombopoietin $(22,24,26-30)$.

Phosphorylation on tyrosine confers DNA-binding activity to the Stat proteins and results in the activation of transcription $(31,32)$. MGF-Stat 5 has originally been identified in mammary gland cells of lactating animals $(33,34)$. MCF-Stat 5 can be induced in cultured mammary epithelial cells by PRL, and its DNA-binding activity is absolutely required for the lactogenic hormone induction of transcription of the $\beta$-casein gene (33). MGF-Stat 5 also confers the PRL response to a $\beta$-casein gene promoter construct when it is introduced together with a PRL receptor gene into nonmammary cells $(22,31)$. MGF-Stat 5 messenger RNA is expressed in different tissues. High levels of expression were found in thymus and spleen $(22,24,25)$. Recent data showed that PRL aclivates a Stat1-related molecule as well as an additional unidentified DNA-binding protein in the T lymphoma cell line $\mathrm{Nb} 2(35,36)$. These results indicate that PRL activates Stat proteins in $\mathrm{T}$ cells.

IL-2 plays a central role in the immune response. It is a primary regulator of $T$ cell proliferation and differentiation (37). IL-2 mediates its effects through interaction with a high affinity receptor comprising three subunits, $\alpha, \beta$, and $\gamma(38)$. The $\beta$ - and $\gamma$-chains are members of the cytokine/hematopoietin receptor family. They transduce signals after IL-2 
binding to its receptor (39). The $\beta$ - and $\gamma$-chains are associated with different signaling molecules. The src family kinases, p56lck and p59fyn, and the Jak family kinase, Jak1, are associated with the $\beta$-chain. The $\gamma$-chain associates with Jak3 $(40-43)$. The association of the Jak kinases with IL-2 receptors and the observation that IL-2 induces DNA-binding activities of Stat elements indicate the involvement of Stat protein in IL-2 receptor signaling $(36,44,45)$.

PRL and IL-2 stimulate the proliferation of the rat $\mathrm{T}$ cell line $\mathrm{Nb} 2$ and induce the transcription of common genes such as the early response gene IRF-1 $(46,47)$. These overlapping activities support the idea that IL-2 and PRL may activate similar transcription factors. We investigated and characterized protein-DNA complexes induced by IL- 2 and PRL in different $\mathrm{T}$ cell lines with regulatory DNA elements known to bind different members of the Stat family. The results show that a Stat5-related factor is activated by IL-2 and PRL in the rat immature $\mathrm{T}$ cell line $\mathrm{Nb} 2$ and by $\mathrm{IL}-2$ in the murine cytotoxic T cell line $\mathrm{Cl} 96$.

\section{Materials and Methods}

\section{Cell culture}

The murine cytotoxic $\mathrm{T}$ cell line $\mathrm{Cl} 96$ was grown in RPMI medium containing $2 \mathrm{mM}$ glutamine, $10 \%$ fetal calf serum (FCS), and $150 \mathrm{U} / \mathrm{ml}$ recombinant human IL-2. Before induction with IL-2, the cells were kept overnight in medium without FCS and then stimulated with $150 \mathrm{U} / \mathrm{ml}$ recombinant human IL-2 for the times indicated. The CD3-specific monoclonal antibody 500A2 $(20 \mu \mathrm{g} / \mathrm{ml})$ was used for activation of the $\mathrm{T}$ cell receptor (TCR). T47D and $\mathrm{Nb} 2$ cells were cultured in RPMI medium containing $2 \mathrm{~mm}$ glutamine and $10 \%$ FCS. Before their induction with cytokines, the cells were deprived of serum for $6 \mathrm{~h}$. They were stimulated with $200 \mathrm{U} / \mathrm{ml}$ IFN $\gamma, 400 \mathrm{U} / \mathrm{ml}$ IL-6 (obtained from Boehringer Mannheim, Indianapolis, IN), $5 \mu \mathrm{g} / \mathrm{ml}$ (T47D cells) or $100 \mathrm{ng} / \mathrm{ml}$ (Nb2 cells) PRL, and $150 \mathrm{U} / \mathrm{ml}$ recombinant human IL-2. COS cells were maintained in Dulbecco's Modified Eagle's Medium containing $10 \%$ FCS and $2 \mathrm{~mm}$ glutamine and were stimulated as previously described (31).

\section{Plasmids and transfections}

Five micrograms of the MGF-Stat 5 expression vector, pXM-MGF, and $5 \mu \mathrm{g}$ of the PRL receptor expression vector were used in the transfection experiments (22). In addition, $0.5 \mu \mathrm{g}$ of the plasmid $\mathrm{pCH} 110$, encoding the $\beta$-galactosidase gene under the control of the simian virus 40 promoter, was included in each transfection as an internal control.

\section{Preparation of nuclear extracts and band shift assays}

Nuclear and cytosolic extracts were prepared as previously described (48) with the following modifications. Nuclei were extracted with a hypertonic buffer containing $20 \mathrm{~mm}$ HEPES (pH 7.9), $400 \mathrm{~mm} \mathrm{NaCl}, 1$ m $\mathrm{EDTA}, 0.1 \%$ Triton $\mathrm{X}-100,20 \%$ glycerol, $1 \mathrm{~mm}$ dithiothreitol, $0.2 \mathrm{~mm}$ phenylmethylsulfonylfluoride, $5 \mu \mathrm{g} / \mathrm{ml}$ leupeptin, and $5 \mathrm{mg} / \mathrm{ml}$ aprotinin for $20 \mathrm{~min}$ at $4 \mathrm{C}$. The extracts were centrifuged at $14,000 \mathrm{rpm}$ for $5 \mathrm{~min}$. Extracts were frozen in liquid nitrogen and stored at $-70 \mathrm{C}$. Cytosolic and nuclear extracts were used for band shift experiments or immunoprecipitations. The protocol for the band shift assays has been previously described (34). The following radioactive probes were used in the band shift experiments: the MGF-Stat5-binding site present in the bovine $\beta$-casein gene promoter ( 5 '-AGATTTCTAGGAATTCAAATC$\left.3^{\prime}\right)$, the acute phase response element (APRE) from the rat $\alpha 2$-macroglobulin gene promoter ( $5^{\prime}$-GATCCTTCTGGGAATTCCTA- $3^{\prime}$ ), and the IRF-1/gamma activated site (GAS) sequence from the IRF-1 gene promoter (5'-GATCCATTTCCCCGAAATGA-3'). The oligonucleotides were end labeled with polynucleotide kinase to a specific activity of 8,000 $\mathrm{cpm} / \mathrm{fmol}$.

\section{Antibodies and Western blot analysis}

Stat1- and phosphotyrosine (4G10)-specific antibodies were purchased from UBI (Lake Placid, NY). Stat2- and Stat4-specific antibodies were obtained from Dr. J. E. Darnell (Rockefeller University, New York, NY). Stat3 (30C)-specific antibodies were obtained from Dr. D. Levy (New York University, New York, NY). Stat5 (N-term)- and (C-term)specific antibodies were produced in chickens. These antibodies are directed against GST-Stat 5 fusion proteins containing either the N-terminal part of Stat 5 from amino acids $6-160$ or the C-terminal part of Stat 5 from amino acids 589-735. Western blot analysis were performed with Stat5 (N-term)- or phosphotyrosine (4G10)-specific antisera at dilutions of 1:1000. Immunoreactive bands were visualized using the epichemiluminescence Western blot system (Amersham, Arlington Heights, IL) according to the manufacturer's protocol.

\section{Oligonucleotide affinity chromatography}

Nuclear extracts were incubated with Sepharose beads coupled to multimerized oligonucleotides. The oligonucleotides consisted of the MGF-Stat5-binding site from the $\beta$-casein gene promoter. The binding reactions were performed for $45 \mathrm{~min}$ at $4 \mathrm{C}$ in a binding buffer containing $100 \mathrm{~mm} \mathrm{NaCl}$ and $30 \mu \mathrm{g}$ poly-deoxy-inosinic-deoxy-cytidylic acid and $30 \mu \mathrm{g}$ poly-deoxy-adenylic-deoxy-rhymidilic acid $/ \mathrm{ml}$. The Sepharose beads were washed three times with binding buffer containing $100 \mathrm{~mm}$ $\mathrm{NaCl}$. The bound proteins were released with sodium dodecyl sulfate (SDS) loading buffer, separated by SDS-polyacrylamide gel electrophoresis, blotted onto a polyvinylidene difluoride membrane, and visualized with a MGF-Stat5- or phosphotyrosine-specific antiserum.

\section{Results}

\section{IL-2 stimulation of cytotoxic $T$ cells induces DNA binding of Stat proteins}

The tyrosine kinases Jak1 and Jak3 are functionally activated by association with the $\beta$ - and $\gamma$-chains of the IL- 2 receptor (42). These kinases are known to activate Stat proteins, and it has been reported that IL-2 stimulation of T cells can induce DNA binding of Stat-like activities $(36,44,45)$. To identify these DNA-binding activities, we performed band shift experiments with nuclear extracts from the mouse cytotoxic $\mathrm{T}$ cell line, Cl96. The cells were treated for increasing times with IL-2 (Fig. 1). The nuclear DNA-binding activities were com-

\begin{tabular}{|c|c|c|c|c|c|}
\hline \multicolumn{2}{|c|}{$\beta$-casein } & \multicolumn{2}{|c|}{ APRE } & \multicolumn{2}{|c|}{ IRF-1-GAS } \\
\hline$\alpha$ CD3 & IL-2 & $\alpha$ CD3 & IL-2 & $\alpha \mathrm{CD3}$ & IL-2 \\
\hline
\end{tabular}

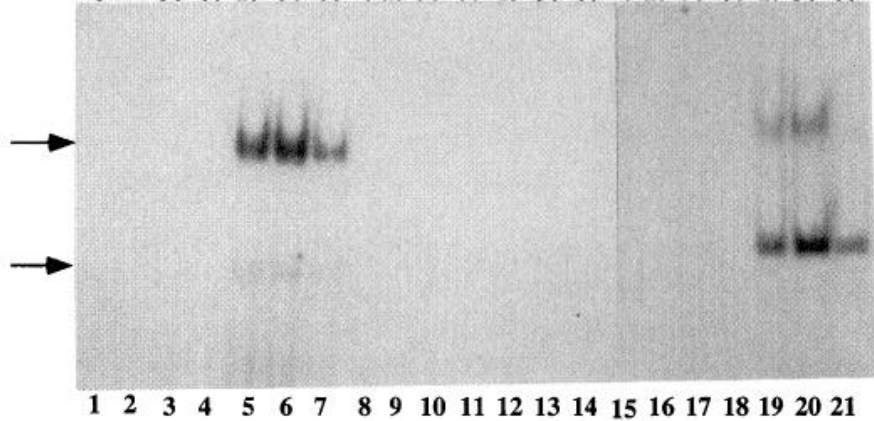

FIG. 1. IL-2 induction of GAS element-specific DNA-binding activities in the cytotoxic T cell line Cl96. Cl96 cells were stimulated with IL-2 or with a CD3-specific monoclonal antibody. After the times indicated, nuclear extracts were prepared and analyzed in band shift assays with a $\beta$-casein gene probe (lanes 1-7), an APRE probe (lanes $8-14$ ), or an IRF-1/GAS probe (lanes 15-21). 
pared to those obtained after TCR activation with a CD3-specific antibody. Three DNA probes were used to visualize binding activities, a probe derived from the sequence of the $\beta$-casein gene promoter (34), the APRE probe (18), and the IRF-1-GAS probe (49). The sequences are shown in Table 1 . These probes bind different members of the Stat family with different affinities. The $\beta$-casein promoter sequence binds most strongly to MGF-Stat5, the APRE probe to Stat3, and the IRF-1-GAS probe to Stat1 (compare Figs. 1 and 2).

IL-2 causes the rapid induction of two DNA-protein complexes when the $\beta$-casein probe is introduced into the band shift assay (Fig. 1, lanes 5-7). Identically migrating DNAbinding activities were observed when the IRF-1/GAS probe was used as a probe (lanes 19-21). Both complexes were maximally induced $30 \mathrm{~min}$ after IL-2 addition to the cells. TCR stimulation did not cause the induction of specific complex formation with the probes used (lanes 1-4, 8-11, and 15-18).

The two complexes are forms with different efficiencies when the $\beta$-casein gene probe or the IRF-1-GAS probe is used. The slower migrating complex binds better to the $\beta$-casein gene probe, and the faster migrating complex binds better to the IRF-1-GAS sequence. None of the proteins forms a detectable complex with the APRE probe (lanes 12-14).

\section{IL-2-induced nuclear proteins share DNA binding specificities with PRL-induced, but not with IFN $\gamma$ - or IL-6- induced, Stat proteins}

To establish the relatedness of the IL-2-induced factor to the members of the Stat family, we compared the DNA binding specificities of Stat proteins induced with different cytokines. The IL-2-induced protein binds preferentially to the $\beta$-casein probe. This suggests that IL- 2 activates a protein related to MGF-Stat5 $(22,33)$. Nuclear extracts from the human mammary carcinoma cell line T47D are useful for this comparison. T47D cells respond to PRL, IFN $\gamma$, and IL-6. DNA-binding activities were visualized with the $\beta$-casein, APRE, or IRF-1-GAS sequence probes (Fig. 2).

DNA protein complexes with different migration behaviors were induced by the three cytokines. The induction with PRL gave rise to a slowly migrating complex, termed complex 1 , when probed with the $\beta$-casein sequence (Fig. $2 \mathrm{~A}$, lanes 4 and 5). A complex with the same mobility was formed when the IRF-1-GAS probe was used (Fig. 2B, lanes 5 and 6). No or very weak binding was observed to the APRE probe (Fig. 2A, lane 8). IFN $\gamma$ induction caused the formation of a more slowly migrating complex (complex 3 ) that can be formed with the $\beta$-casein probe (Fig. $2 A$, lanes 2 and 3 ), the IRF-1-GAS probe (Fig. 2B, lanes 1 and 2), and the APRE probe (Fig. 2A, lane 10). IL-6 induced three DNA-binding complexes (Fig. 2A, lane 6, and Fig. 2B, lanes 3 and 4). These complexes were formed with the $\beta$-casein (Fig. 2A, lane 6), APRE (lane 9), and IRF-1-GAS (Fig. 2B, lane 4) probes. The complexes activated by IL-6 were down-regulated after $1 \mathrm{~h}$

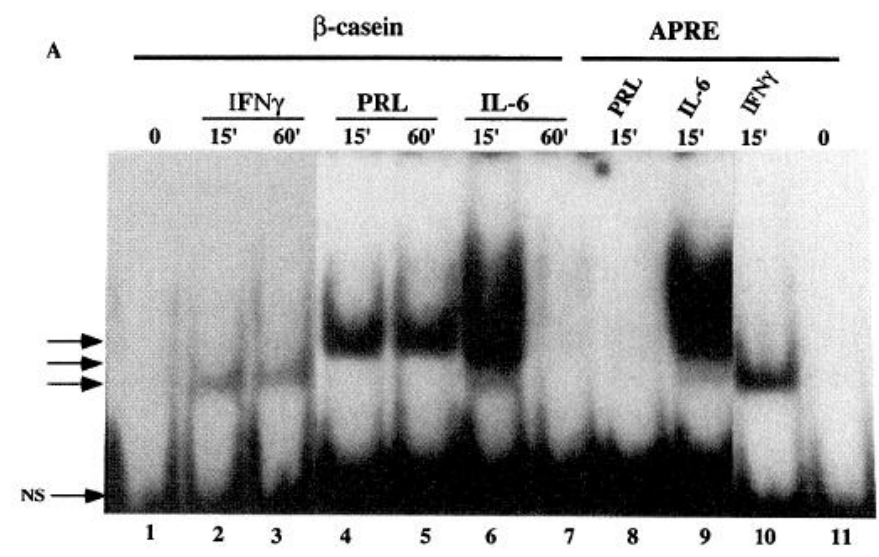

B
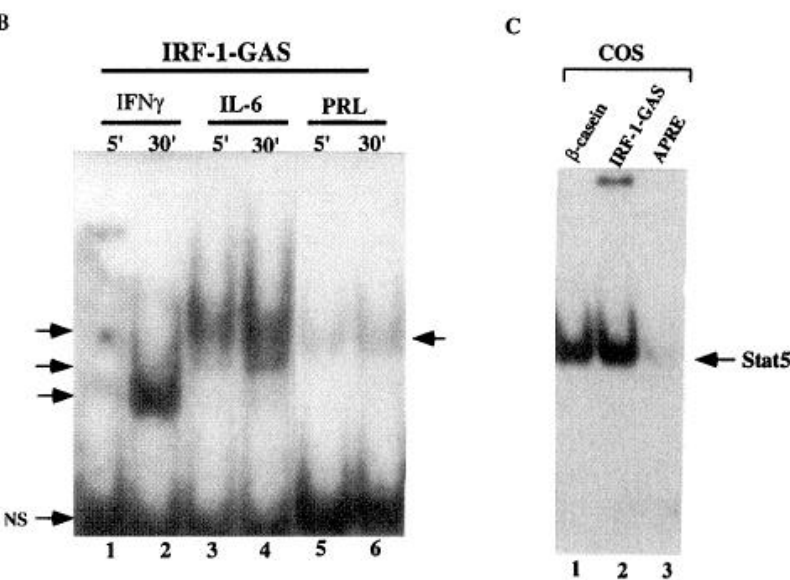

FIG. 2. IFN $\gamma$, IL-6, and PRL activate Stat factors with distinct DNA binding specificities in the mammary carcinoma cell line T47D. A, T47D cells were treated for the times indicated with IFN $\gamma(200 \mathrm{U} / \mathrm{ml})$, IL-6 $(400 \mathrm{U} / \mathrm{ml})$, and PRL $(1 \mu \mathrm{g} / \mathrm{ml})$. Nuclear extracts were prepared and analyzed in band shift experiments with a $\beta$-casein gene probe (lanes 1-7) and an APRE probe (lanes 8-11). B, Analysis of the cytokine-induced factors in nuclear extracts from T47D-treated cells with an IRF-1/GAS probe. C, MGF/Stat5 binding to different GAS elements. Nuclear extracts from PRL-induced COS cells transfected with expression vectors for the PRL receptor and MGF-Stat5 were analyzed in band shift experiments with the $\beta$-casein gene (lane 1), IRF-1/GAS (lane 2), and APRE (lane 3) probes. NS, Nonspecific activity. The arrows in A and B indicate the positions of migration of individual DNA-protein complexes. The upper arrow denotes complex 1 , the middle arrow complex 2, and the lower arrow complex 3.

(Fig. 2A, lane 7). This was not observed for the DNA-binding activities induced by PRL and IFN $\gamma$.

The electrophoretic migration of the MGF-Stat5 DNA complex and the binding specificity of MGF-Stat 5 with respect to the three DNA probes were compared to the PRL-, IFN $\gamma$-, and IL-6-induced activities. MGF-Stat 5 activity was obtained from transfected COS cells (Fig. 2C). MGF-Stat5 bound preferentially to the $\beta$-casein and IRF-1-GAS sequences and only weakly to the APRE sequence. The electrophoretic migration

TABLE 1. Sequences of the DNA probes 
of the MGF-Stat 5 complex was indistinguishable from that of the IL-2-induced activity. These experiments indicate that the IL-2-induced DNA-binding protein from T cells, the PRLinduced protein from T47D cells, and MGF-Stat 5 from transfected COS cells share similar DNA binding specificities.

The major IL-2-induced DNA complex from $T$ cells contains a protein immunologically cross-reactive with MGF-Stat5

Antisera specific for Stat1, Stat2, Stat3, Stat4, and Stat5 were employed to characterize the proteins present in the DNA complexes induced by IL-2. IFN $\gamma$, IL-6, and PRL activate distinct members of the Stat family. As T47D cells can be induced with all three cytokines, we used nuclear extracts from these cells to demonstrate the specificity of our antisera. Nuclear extracts from T47D treated with IFN $\gamma$, IL-6, and PRL were incubated with the IRF-1-GAS probe, and the complexes were visualized in band shift assays (Fig. 3). The complexes induced by IFN $\gamma$, IL-6, and PRL were incubated with the Stat antisera. The appearance of more slowly migrating complexes (supershifts) was monitored.

The Stat1 antiserum causes a supershift of the complex induced by IFN $\gamma$ (Fig. 3, lane 2), and the fastest migrating complex (complex 3 ) induced by IL-6 (lane 8 ). The second complex (complex 2) induced by IL-6 was partially shifted (lane 8). Complex 2 and the slowest migrating complex (complex 1), but not complex 3, were supershifted by the Stat3 antiserum (lane 10). The antisera directed against Stat2, Stat4, and Stat 5 were not able to supershift the complexes activated by IFN $\gamma$ and IL- 6 (lanes 3, 5, 6, 9, 11, and 12). This observation is consistent with the idea that IFN $\gamma$ activates and promotes the homodimer formation of Stat1. IL-6 caused the formation of Stat1 and Stat3 homodimers and that of Stat1 and Stat3 heterodimers in T47D cells. The PRL-induced complex from T47D was only supershifted by Stat5 antiserum (lane 19). Antisera raised against individual members of the Stat family clearly distinguished the DNA-protein complexes formed by these proteins in band shift experiments.

We examined the complex induced by IL- 2 in $\mathrm{Cl} 96$ cells by immunological means. Complexes were formed with the IRF-1-GAS probe and the $\beta$-casein probe (Fig. 4). The complexes formed with these probes could be distinguished (compare Fig. 4A, lane 1, with Fig. 4B, lane 1). With the

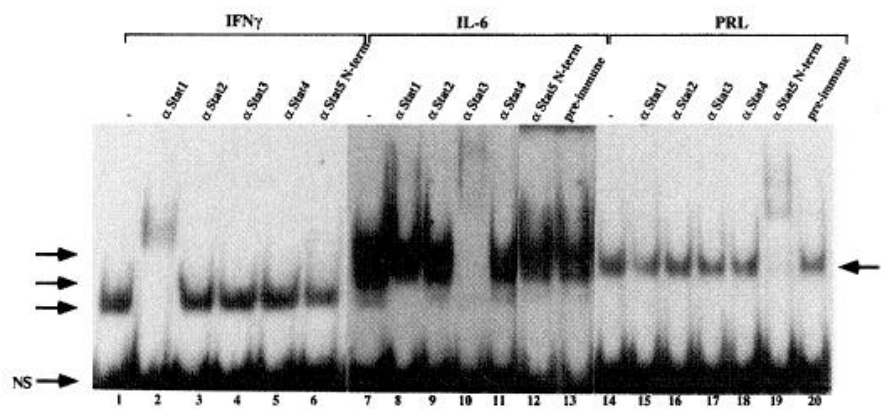

FIG. 3. Stat-specific antisera distinguish among IFN $\gamma-$, IL-6-, and PRL-induced factors. Nuclear extracts from IFN $\gamma$-treated (lanes 1-6), IL-6-treated (lanes 7-13), and PRL-treated (lanes 14-20) T47D cells were incubated with antisera raised against individual members of the Stat factor family and assayed for binding to the IRF-1 probe in band shift experiments. NS, Nonspecific activity.
A

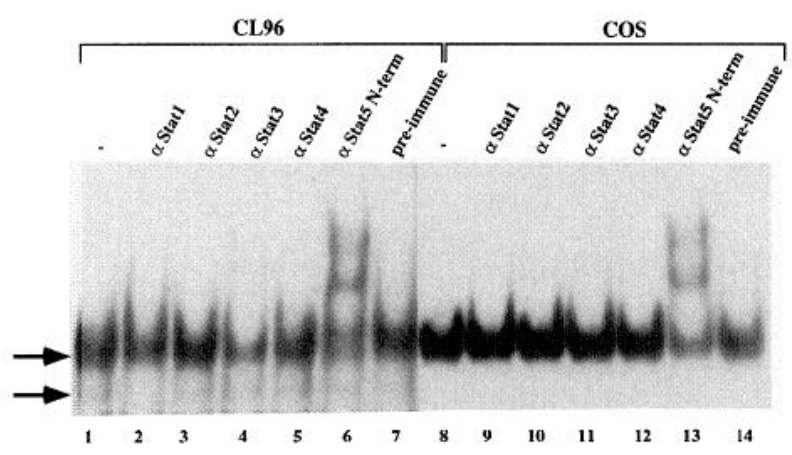

B

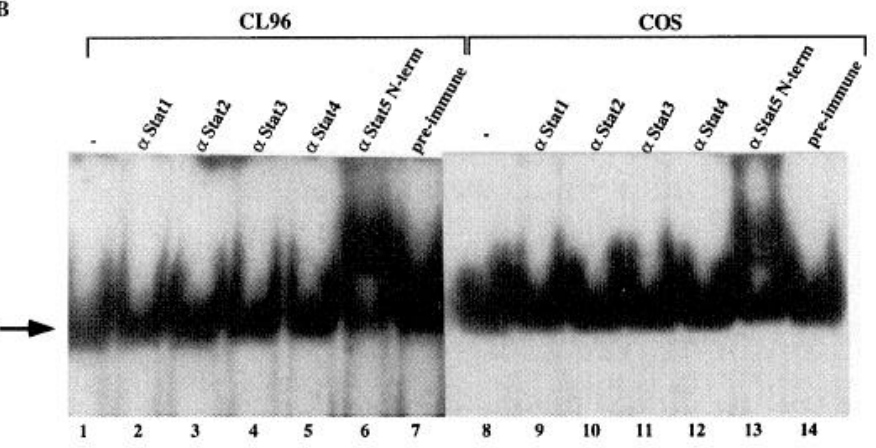

FIG. 4. IL-2 activates a factor immunologically related to Stat5 in Cl96 cells. A, Nuclear extracts from IL-2-treated C196 cells (lanes 1-7) or COS cells transfected with expression vectors for the PRL receptor and MGF-Stat5 (lanes 8-14) were incubated with antisera specific for individual Stat proteins and assayed for binding to the IRF-1 probe in band shift experiments. B, The nuclear extracts were assayed with the $\beta$-casein gene probe.

IRF-1-GAS probe, in addition to the major complex, a minor second, faster migrating band was observed. This faster migrating complex was not formed with extracts from COS cells containing activated MGF-Stat5 (Fig. 4A, lane 8). The minor complex could not be observed after the addition of Stat1 antiserum (Fig. 4A, lane 2). The major complex formed by IL-2 bound to both probes. This complex only reacted with Stat5 antiserum. Similar to the situation found after the induction of T47D cells with PRL, IL-2 in Cl96 cells primarily activated a protein related to Stat5. A protein immunologically related to Stat1 was induced to a lesser extent.

\section{$P R L$ and IL-2 activate a Stat5-related molecule in the T lymphoma cell line $\mathrm{Nb2}$}

The rat $\mathrm{T}$ lymphoma cell line $\mathrm{Nb} 2$ responds to PRL and IL-2. Both cytokines are mitogens for the Nb2 cells (46) and activate Jak and latent transcription factors $(35,36)$. These putative Stat factors bind to the IRF-1-GAS sequence, but have not yet been fully characterized. To further demonstrate that PRL and IL-2 activate closely related transcription factors, we investigated the Stat proteins induced in $\mathrm{Nb} 2$ cells.

Nuclear extracts were prepared from $\mathrm{Nb} 2$ cells treated for increasing lengths of times with IL-2 or PRL and analyzed in band shift experiments. Complexes formed with the IRF-1GAS and $\beta$-casein probes were compared (Fig. 5). Two complexes were observed after stimulation of the cells with PRL 


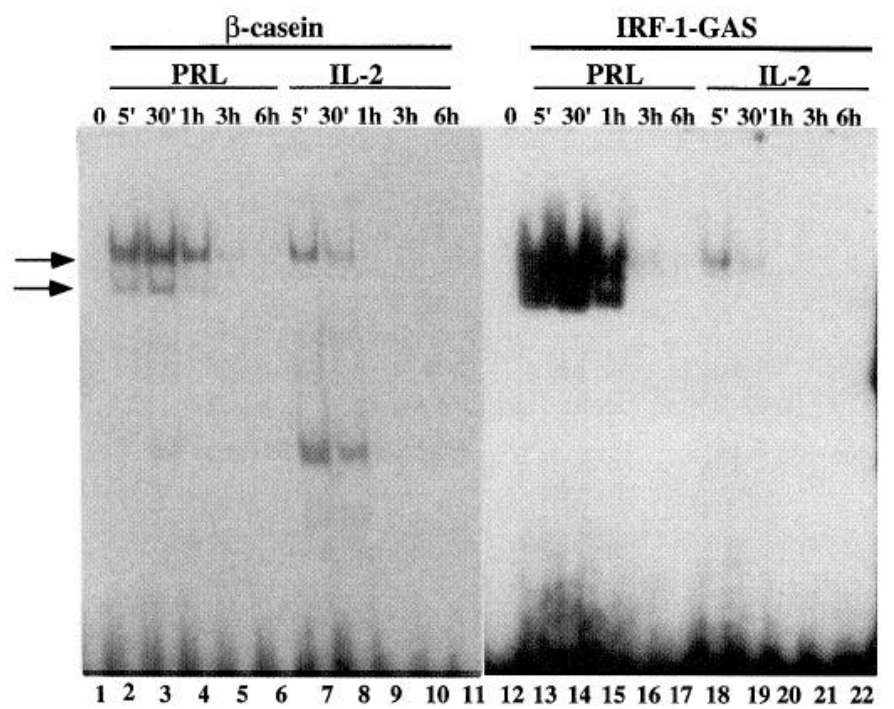

FIG. 5. PRL and IL-2 activate distinct patterns of DNA-binding activities in Nb2 cells. Nb2 cells were treated with PRL (lanes 2-6 and 13-17) or IL-2 (lanes 7-11 and 18-22) for the times indicated. Nuclear extracts were prepared and analyzed in band shift experiments with a $\beta$-casein gene probe (lanes 1-11) or an IRF-1/GAS probe (lanes 12-22).

(Fig. 5, lanes 2, 3, 4, and 13-15). The induced proteins bound differently to the $\beta$-casein probe and the IRF-1-GAS probe. IL-2 induced a complex that comigrates with the slower migration complex induced by PRL (Fig. 5, lanes 7, 8, 18, and 19). The kinetics of activation of the PRL- or IL-2-induced complex were different. The PRL-induced complex reached maximal intensity after $30 \mathrm{~min}$ (lanes 3 and 14) and declined after $1 \mathrm{~h}$ (lanes 4 and 15). The IL-2 induced complex was already maximally induced after 5 min (lanes 7 and 18) and only weakly detectable after $30 \mathrm{~min}$ (lanes 8 and 19). The fast migrating complexes observed in lanes 7 and 8 were nonspecific. Their formation could not be competed with an excess of nonradioactive oligonucleotide.

We examined the protein-DNA complexes induced by IL-2 and PRL in Nb2 cells with antibodies that recognize individual Stat factors. The complexes were incubated with the specific antisera and analyzed in band shift experiments

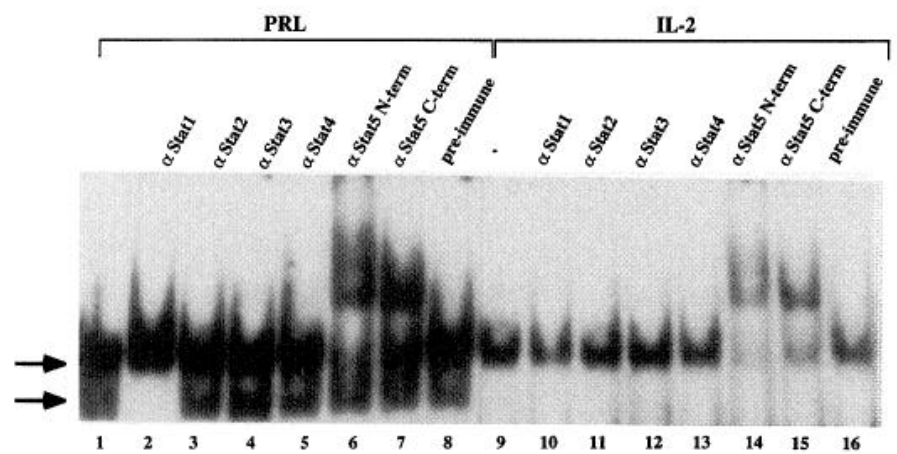

FIG. 6. PRL and IL-2 activate a Stat5-like factor in $\mathrm{Nb} 2$ cells. Nuclear extracts from PRL- or IL-2-stimulated cells were incubated with antiStat1 (lanes 2 and 10), anti-Stat2 (lanes 3 and 11), anti-Stat3 (lanes 4 and 12), anti-Stat4 (lanes 5 and 13), anti-Stat5 N-term (lanes 6 and 14 ), or anti-Stat5 C-term (lanes 7 and 15) serum or with preimmune serum (lanes 8 and 16) and assayed for binding activity to a $\beta$-casein gene probe in band shift experiments.
(Fig. 6). The more slowly migrating complex induced by PRL was supershifted with antisera specific for MGF-Stat5 (lanes 6 and 7). These antisera were derived against the $\mathrm{N}$ - and C-terminal ends of MGF-Stat5. The faster migrating complex induced by PRL was supershifted with the Stat1-specific antiserum (lane 2). The complex activated by IL-2 was supershifted by the two antisera specific for MGF-Stat5 (lanes 14 and 15). It was not reactive with antisera specific for Stat 1 (lane 10), Stat 2 (lane 11), Stat 3 (lane 12), or Stat 4 (lane 14) or with preimmune serum (lane 16). These results indicated that PRL and IL-2 activate a Stat5-related molecule in $\mathrm{Nb} 2$ cells. PRL, but not IL-2, is able to stimulate the DNA-binding activity of a Stat1-related molecule in $\mathrm{Nb} 2$ cells.

\section{Induction of the Stat1-related protein requires higher PRL concentrations than induction of the Stat5-related factor}

The induction of a Stat1-related complex by PRL seems to be cell type dependent. When COS cells transfected with PRL receptor and MGF-Stat 5 expression vectors were stimulated with PRL, only the activation of Stat5, not that of Stat1, was observed. The presence and inducibility of Stat1 in COS cells were shown after IFN $\gamma$ induction (Gouilleux, F., unpublished data). $\mathrm{Nb} 2$ cells express high levels of a truncated form of the PRL receptor and are very sensitive to PRL (50). The induction of the Stat1-DNA complex by PRL might be dependent on signal strength and the concentration of PRL in the culture medium. We treated $\mathrm{Nb} 2$ cells with increasing concentration of PRL for $30 \mathrm{~min}$. Nuclear extracts were prepared and analyzed for the presence of Stat1- and Stat5containing DNA complexes (Fig. 7). The Stat5-containing complex was weakly induced by $1 \mathrm{ng} / \mathrm{ml} \mathrm{PRL}$ (lane 2) and strongly by $5 \mathrm{ng} / \mathrm{ml}$ (lane 3 ). The Stat1-containing complex was formed only weakly after induction with $25 \mathrm{ng} / \mathrm{ml}$ PRL (lane 4) and strongly with $125 \mathrm{ng} / \mathrm{ml}$ (lane 5). At low PRL concentrations, Stat 5 was predominantly activated.

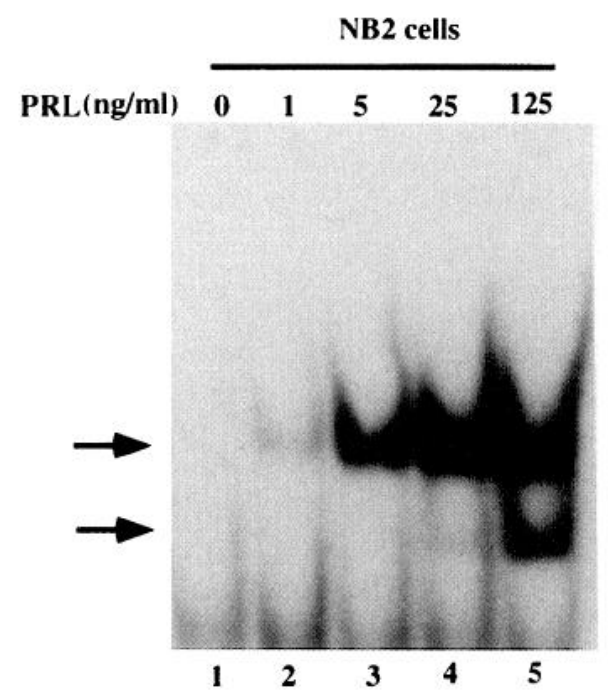

FIG. 7. Differential activation of Stat proteins in $\mathrm{Nb} 2$ cells in response to increasing concentrations of PRL. Cells were treated for 30 min with $1 \mathrm{ng} / \mathrm{ml}$ (lane 2), $5 \mathrm{ng} / \mathrm{ml}$ (lane 3), $25 \mathrm{ng} / \mathrm{ml}$ (lane 4), and 125 $\mathrm{ng} / \mathrm{ml}$ (lane 5) PRL. Nuclear extracts were prepared and analyzed in band shift experiments with a $\beta$-casein gene probe. 
IL-2- and PRL-induced DNA-protein complexes from $T$ cells have identical DNA binding specificities

We compared the DNA binding of the nuclear factors induced by IL- 2 in $\mathrm{Cl} 96$ cells and by IL- 2 and PRL in Nb2 cells to oligonucleotide probes that differed slightly in their sequence. The IRF-1-GAS, APRE, and $\beta$-casein oligonucleotides comprise the palindromic sequence $5^{\prime}$-TTCNNNGAA$3^{\prime}$. This palindromic sequence is essential for DNA binding of MGF-Stat5 $(28,48)$. However, although the APRE probe contains this sequence motif, no or very weak DNA binding of MGF-Stat 5 to this probe was detected (Fig. 3A). This suggests that additional bases are important for MGF-Stat 5 binding. A recent report indicated that the spacing between TTC and GAA half-palindromic sites as well as the sequences flanking them might be determinants for DNA binding and transcriptional activation (51).

Oligonucleotide probes were derived that deviate in one or two nucleotide positions from the palindromic MGFStat5-binding site found in the $\beta$-casein gene promoter. The variant oligonucleotides (Fig. 8A) were used as nonradioactive competitors in band shift experiments (Fig. 8B). The wild-type sequence was used as a radioactive probe. Nuclear extracts were prepared from IL-2-induced $\mathrm{Cl} 96$ cells and IL-2- or PRL-induced Nb2 cells.

Oligonucleotides B12.13 (Fig. 8B, lanes 4 and 5) and B5.6 (lanes 14 and 15) were not able to compete with the binding of IL-2- or PRL-induced proteins to the wild-type oligonucleotide. B12.13 contains two G's at positions 12 and 13 (wild type contains two A's), and oligonucleotide 5.6 contains two $\mathrm{C}^{\prime} \mathrm{s}$ at positions 5 and 6 (wild type contains two T's). Very weak competitions with the MGF-Stat5-containing, more slowly migrating complex were observed with oligonucleotides B11 (lanes 6 and 7; change of A for G at position 11) and B7 (lanes 12 and 13; change of $\mathrm{T}$ for $\mathrm{C}$ at position 7). In contrast, the faster migrating Stat 1 containing complex induced by PRL in Nb2 cells is efficiently competed by oligonucleotides B11 and B7. This suggests that differently from MGF-Stat 5 binding, the Stat1-specific sequence does not require the presence of $\mathrm{a} G$ at position 11 or a $\mathrm{C}$ at position 7 .

The oligonucleotides B10 (Fig. 8, lanes 8 and 9; change of A for $\mathrm{G}$ at position 10) and B8.9 (lanes 10 and 11; changes of CG for TA at positions 8 and 9) competed the formation of both Stat1- and MGF-Stat5-containing complexes induced by IL-2 and PRL. Oligonucleotide B10 was slightly less efficient. The same observation was made earlier when transfected MGF-Stat5 DNA binding was investigated (28).

These results indicate that the Stat5-related factor induced by IL- 2 and PRL in T cells and authentic MGF-Stat 5 require the same palindromic sequences for DNA binding. The three nucleotides between the TTC and GAA palindromic halfsites modulate the DNA-binding affinity of the PRL- and IL-2-induced Stat5-like factors. The specificities are indistinguishable from that of authentic MGF-Stat5.

\section{IL-2- and PRL-induced DNA-binding proteins have the same mol wt as MGF-Stat5}

IL-2 induced protein-DNA complexes in $\mathrm{Nb} 2$ cells and Cl-96 cells that could be supershifted with a MGF-Stat5-
A

$$
\begin{aligned}
& \text { Wild type 5'-AGATTTCTAGGAATTCAATC- } 3 \\
& \text { B12.13 5'-AGATTTCTAGG GGTTCAATC-3' } \\
& \text { B11 5'-AGATTTCTAG@AATTCAATC-3' }
\end{aligned}
$$

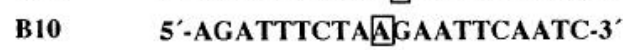

$$
\begin{aligned}
& \text { B8.9 5'-AGATTTCCGGGAATTCAATC-3' } \\
& \text { B7 5'-AGATTIUTRAGGATTCAATC-3 } \\
& \text { B5.6 5'AGATCOCTAGGAATTCAATC-3' }
\end{aligned}
$$

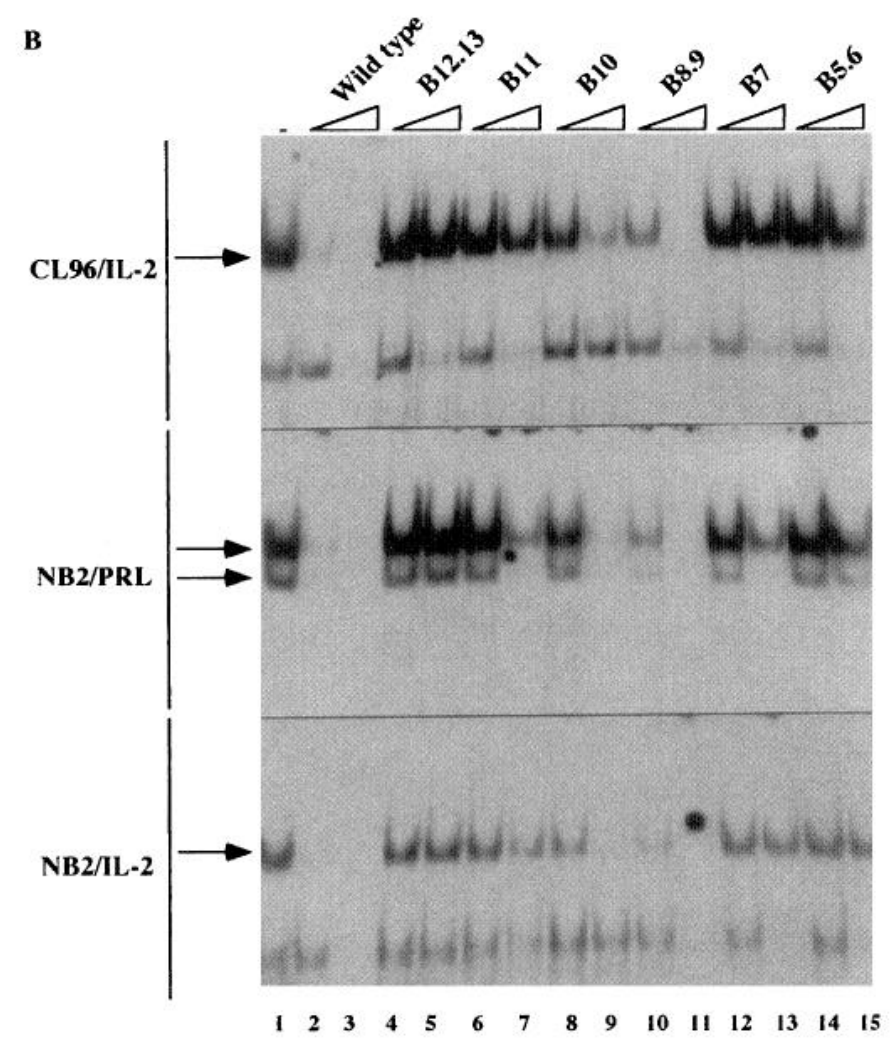

FIG. 8. The Stat5-like factors induced by IL-2 in Cl96 and those induced by IL- 2 and PRL in Nb2 cells have very similar DNA binding specificities. A, The MGF-Stat5-binding site from the $\beta$-casein gene promoter and the variants derived from this sequence used in the oligonucleotide competition experiments are shown. B, Nuclear extracts were prepared from IL-2-treated Cl96 cells (upper panel) and from PRL-treated (middle panel) and IL-2-treated (lower panel) $\mathrm{Nb2}$ cells. Band shift experiments were carried out with the $\beta$-casein gene probe. Nonradioactive competitor oligonucleotides were introduced, as indicated, into the binding reaction in a 10-fold (lanes $2,4,6,8,10$, 12 , and 14) and a 100-molar (lanes $3,5,7,9,11,13$, and 15) excess.

specific antiserum. The complexes exhibited DNA binding specificities very similar to those of MGF-Stat5-containing complexes. To further strengthen the evidence that the IL2-induced protein corresponds to MGF-Stat5, the mol wt of the IL-2-induced factor was determined.

Nuclear extracts from Nb2 cells treated with IL-2 or PRL were prepared, and the specific DNA binding proteins were partially purified by affinity chromatography. The extracts were incubated with multimerized MGF-Stat5-binding sites coupled to Sepharose beads. Bound proteins were eluted, fractionated by SDS-polyacrylamide gel electrophoresis, and blotted onto filters, and the filters were developed with MGF- 
A

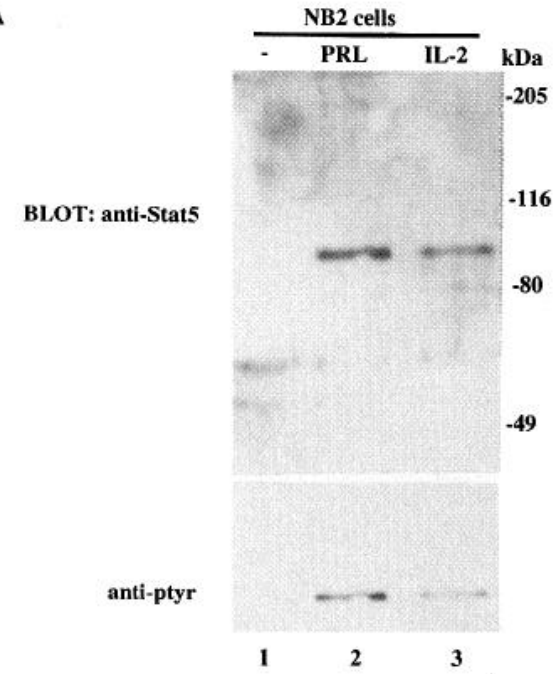

B

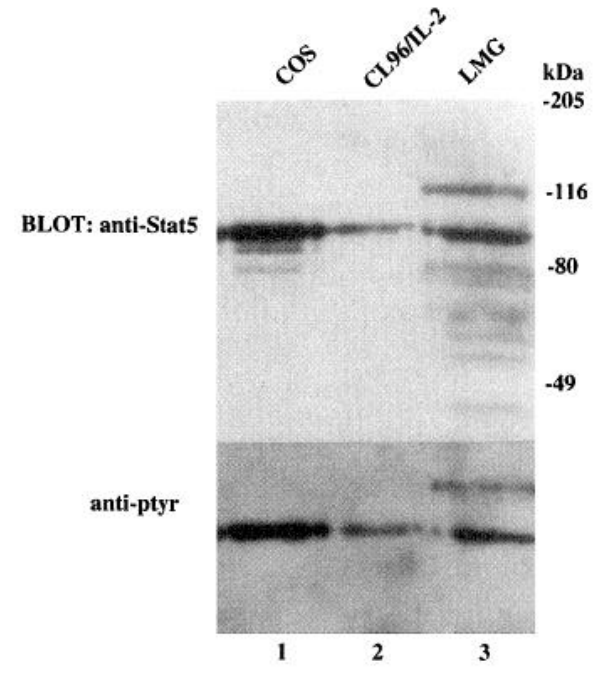

FIG. 9. IL-2- and PRL-activated Stat proteins have mol wt similar to that of MGF-Stat5. A, Nuclear extracts from untreated (lane 1), IL-2-treated (lane 2), or PRL-treated (lane 3) Nb2 cells were incubated with the multimerized $\beta$-casein gene oligonucleotide bound to Sepharose beads as described in Materials and Methods. Bound proteins were eluted from the beads, analyzed by Western blotting with a MGF-Stat5specific antibody (upper panel), and reprobed with antiphosphotyrosine-specific antibody (lower panel). B, Oligonucleotide affinity purification was performed with nuclear extracts from COS cells transfected with MGF-Stat5 and PRL receptor expression vectors and induced with PRL (lane 1), from Cl96 cells treated with IL-2 (lane 2), and from mammary gland cells from lactating rats (lane 3). The migration positions of marker proteins are indicated.

Stat5-specific antiserum (Fig. 9A). The antiserum recognized a protein with an apparent mol wt of 92 kilodaltons $(\mathrm{kDa})$ from IL-2- and PRL-treated cells. This protein was not present in nuclear extracts from untreated cells. The $92-\mathrm{kDa}$ protein is phosphorylated on tyrosine. It was also detected when the membrane was probed with an phosphotyrosinespecific antibody (4G10).

An affinity selection experiment was performed with nuclear extracts from IL-2-treated Cl96 cells, nuclear extracts from mammary gland cells of lactating rats, and nuclear extracts from COS cells transfected with MGF-Stat5 (Fig. 9B). A 92-kDa protein was recognized by the MGF-Stat5-specific antiserum in the proteins from all three extracts. The $92-\mathrm{kDa}$ proteins were also tyrosine phosphorylated (lower panel). An additional protein with a mol wt of about $116 \mathrm{kDa}$ was recognized by the MGF-Stat5-specific antiserum in the nuclear proteins derived from the mammary gland cells (lane 3 ). This protein was also tyrosine phosphorylated and might represent a new isoform or a homolog of Stat5 $(26,27)$.

\section{Discussion}

PRL and IL-2 activate nuclear DNA-binding proteins in T cells. PRL-induced factor and PRL-stimulated factor have been described $(35,36)$ in studies on the $\mathrm{Nb} 2 \mathrm{~T}$ lymphoma cell line. Here we show that the PRL- and IL-2-activated Stat protein in T cells is highly related to MGF-Stat5. The Stat proteins activated by IL-2 and PRL in the T cell lines $\mathrm{Nb} 2$ and $\mathrm{Cl} 96$ form complexes with the same DNA binding specificities, immunoreactivities, and electrophoretic migration properties as MGF-Stat5 found in mammary epithelial cells or MGF-Stat 5 transfected into COS cells. The conclusion that IL-2 can cause the activation of a MGF-Stat5-like factor was also reached in experiments in which CTLL-2 cells (52) and transfected BA/F3 (45) were analyzed. Because closely re- lated homologs of Stat5 exist, formal proof of the identity of these factors with MGF-Stat 5 can only be obtained by the molecular cloning of the corresponding complementary DNA from $T$ cells. Stat5a and Stat $5 b$ have been recently cloned from a mast cell line complementary DNA library, and several isoforms have been identified and characterized from myeloid cell lines and mammary epithelial cells (2427). Isoforms might also be present in $\mathrm{Nb} 2$ or $\mathrm{Cl} 96$ cells that can become activated by IL-2 and PRL.

The IL-2- and PRL-induced Stat protein in Nb2 cells reacted with antisera raised against the $\mathrm{N}$ - and C-terminals of the MGF-Stat 5 molecule. The Stat 5 antiserum raised against the N-terminus recognizes specifically Stat $5 \mathrm{a}$, but not Stat $5 \mathrm{~b}$, although they share $96 \%$ identity at the amino acid level (25). These properties suggests that in Nb2 cells, IL-2 and PRL activate a highly related factor. We investigated the Stat5 isoforms induced by IL- 2 in Cl96 cells. Stat5a- and Stat5bspecific antisera, prepared and provided by the laboratory of L. Hennighausen (Bethesda, MD), were used in supershift experiments. We found that IL-2-induced DNA binding complexes contained both Stat $5 a$ as well as Stat5b.

MGF-Stat 5 was originally identified as a transcription factor that confers a PRL response to milk protein gene promoters, and its action was initially considered to be tissue specific $(22,33)$. Recently, it was shown that MGF-Stat5 can mediate the transcriptional response to other growth factors and cytokines. We and others reported that a Stat5-related factor is activated in hematopoietic cell lines in response to erythropoietin, IL-3, GM-CSF, and thrombopoietin (24, 26, $28,29)$ and that $\mathrm{GH}$ transcriptional activation of the serine protease inhibitor 2.1 gene promoter is dependent on MGFStat5 (30). These cytokines stimulate the proliferation of hematopoietic cells and trigger their differentiation programs.

What is the physiological significance of the activation of a MGF-Stat5-like factor by PRL and IL-2 in T lymphocytes? 
PRL and IL-2 both act as mitogens for T cells (46) and regulate their proliferation by the induction of essential growth-promoting genes, such as c-myc, c-fos, ornithine decarboxylase, and IRF-1 $(47,53)$. The transcriptional regulation of these genes might be achieved through Stat 5 activation. The IRF-1 gene promoter contains a p91-Stat1-binding site in the interferon response element. This element mediates transcription of the IRF-1 gene by IFN $\gamma$ and IL-6 $(49,54)$. The Stat5-like factors activated by IL-2 and PRL in Nb2 and C196 cells can also bind to this interferon response element-GAS element of the IRF-1 gene promoter. The involvement of Stat5-like factors in the IRF-1 gene transcription might be complex. IL-2 induces transcription of the IRF-1 gene by a mechanism requiring ongoing protein synthesis. PRL induces transcription by two different mechanisms, one depending on ongoing protein synthesis, and the other independent of it (53). It is possible that both cytokines induce the DNA-binding activity of the Stat5-like factor to the IRF-1-GAS element, but that this binding activity might have to be complemented by a second event to effect IRF-1 gene transcription. We recently reported examples in which the DNA-binding activity of MGF-Stat 5 and its transactivation potential could be distinguished (28).

In addition to the activation of a Stat5-like activity, PRL in $\mathrm{Nb} 2$ cells or IL-2 in Cl96 stimulated the DNA-binding activity of a Stat1-like factor. This factor preferentially binds to the IRF-1-GAS element of the IRF-1 gene compared to the MGFStat5-binding site in the $\beta$-casein gene promoter. Activation of Stat 1 by PRL has not been observed in COS cells transfected with the PRL receptor expression vector, although a Stat1-like factor was induced with IFN $\gamma$ in these cells. Stat1 induction was also not observed in T47D cells after PRL stimulation and in Nb2 cells after IL-2 induction. These results suggest that differential activation of Stat proteins by individual cytokines is possible and cell type dependent.

$\mathrm{Nb} 2$ cells respond to very low concentrations of PRL in the cell culture medium. This increased sensitivity might be related to the high number, the particular splice variant of the PRL receptor expressed in these cells, or auxiliary cellular components present in Nb2 cells, but not in COS or T47D cells. These properties might allow PRL activation of a Stat1like factor in $\mathrm{Nb} 2$ cells. It is noteworthy that the Stat1-like factor is only induced by high concentrations of PRL in the culture medium. This is reminiscent of the differential activation of Stat proteins in response to increasing amounts of IL-6 (55). The Stat1- and Stat5-like factors activated by PRL in $\mathrm{Nb} 2$ cells have different DNA binding preferences. It is conceivable that the genes regulated by low or high concentrations of PRL differ and that a dose-dependent biological response can be observed.

Not only PRL, but also GH, has been implicated in the development and function of $\mathrm{T}$ cells. The hormones have been identified as paracrine growth and differentiation factors in the hematopoietic system $(3,8)$. Our observation that IL-2 can activate a Stat5-like transcription factor similar to a factor that can also be activated by PRL and GH could shed light on the mechanisms governing the redundant action of cylokines. Identification of genes regulated by Stat 5 in $\mathrm{T}$ lymphocytes in response to the individual cytokines will be important to decipher their common and their distinct roles.

\section{Acknowledgments}

We thank Dr. Isabelle Dusanter-Fourt (Paris, France) for providing the Nb2 cells, and George Achenbach and Peter Müller (Basel, Switzerland) for the synthesis of oligonucleotides.

\section{References}

1. Kelly PA, Djiane J, Postel-Vinay MC, Edery M 1991 The prolactingrowth hormone receptor family. Endocr Rev 12:235-251

2. Gala RR 1991 Prolactin and growth hormone in the regulation of the immune system. Proc Soc Exp Biol Med 198:513-527

3. Hooghe R, Delhase M, Vergani P, Malur A, Hooghe-Peters EL 1993 Growth hormone and prolactin are paracrine growth and differentiation factors in the haemopoietic system. Immunol Today 14:212214

4. Gagnerault MC, Touraine P, Savino W, Kelly PA, Dardenne M 1993 Expression of prolactin receptors in murine lymphoid cells in normal and autoimmune situations. J Immunol 12:5673-5681

5. Neal KD, Montgomery DW, Truong TM, Yu-Lee LY 1992 Prolactin gene expression in human thymocytes. Mol Cell Endocrinol 87:R19R23

6. Pellegrini I, Lebrun JJ, Ali S, Kelly PA 1992 Expression of prolactin and its receptor in human lymphoid cells. Mol Endocrinol 6:10231031

7. Clevenger CV, Sillman AL, Hanley-Hyde J, Prystowsky MB 1992 Requirement for prolactin during cell cycle regulated gene expression in cloned T-lymphocytes. Endocrinology 130:3216-3222

8. Murphy JM, Durum SK, Longo DL 1993 Differential effects of growth hormone and prolactin on murine $\mathrm{T}$ cell development and function. J Exp Med 178:231-236

9. Tanigushi T 1995 Cytokine signaling through non-receptor protein tyrosine kinases. Science 268:251-255

10. Rui H, Kirken RA, Farrar WL 1994 Activation of receptor-associated tyrosine kinase Jak2 by prolactin. J Biol Chem 269:1-5

11. Clevenger CV, Torigoe T, Reed JC 1994 Prolactin induces rapid phosphorylation and activation of prolactin receptor-associated RAF-1 kinase in a T-cell line. J Biol Chem 269:5559-5565

12. Dusanter-Fourt I, Muller O, Ziemiecki A, Mayeux P, Drucker B, Djiane J, Wilks A, Harpur AG, Fischer S, Gisselbrecht S 1994 Identification of Jak protein tyrosine kinases as signaling molecules for PRL. Functional anlysis of PRL receptor and PRL-erythropoietin receptor chimeras expressed in lymphoid cells. EMBO J 13:25832591

13. Darnell JE, Kerr IM, Stark GR 1994 Jak-Stat pathways and transcriptional activation in response to IFNs and other extracellular signaling proteins. Science 264:1415-1421

14. Ihle JN, Kerr IM 1995 Jaks and Stats in signaling by the cytokine receptor superfamily. Trends Genet 2:69-74

15. Shuai K, Schindler C, Prezioso VR, Darnell JE 1992 Activation of transcription by IFN- $\gamma$ : tyrosine phosphorylation of a $91-\mathrm{kD}$ DNA binding protein. Science 259:1808-1812

16. Fu XY, Schindler C, Improta T, Aebersold R, Darnell JE 1992 The proteins of ISGF-3, the interferon alpha-induced transcriptional activator, define a gene family involved in signal transduction. Proc Natl Acad Sci USA 89:7840-7843

17. Schindler C, Fu XY, Improta T, Aebersold R, Darnell JE 1992 Proteins of transcription factor ISGF-3: one gene encodes the 91- and $84-k D a$ ISGF-3 proteins that are activated by interferon $\alpha$. Proc Natl Acad Sci USA 89:7836-7839

18. Akira S, Nishio $Y$, Inoue $M$, Wang XJ, Wei S, Matsusaka $T$, Yoshida K, Sudo T, Naruto M, Kishimoto T 1994 Molecular cloning of APRF, a novel IFN-stimulated gene factor 3 p91-related transcription factor involved in the gp130-mediated signaling pathway. Cell 77:63-71

19. Zhong Z, Wen Z, Darnell JE 1994 Stat3: a STAT family member activated by tyrosine phosphorylation in response to epidermal growth factor and interleukin-6. Science 264:95-98

20. Jacobson NG, Szabo S, Weber-Nordt RM, Zhong Z, Schreiber RD, Darnell JE, Murphy KM 1995 Interleukin 12 activates Stat3 and Stat 4 by tyrosine phosphorylation in T cells. J Exp Med 181:17551762

21. Yamamoto K, Quelle FW, Thierfelder WE, Kreider BI., Gilbert DJ, 
Jenkins NA, Copeland NG, Silvenoinnen O, Thle JN 1994 STAT4, a novel gamma interferon activation site-binding protein expressed in early myeloid differentiation. Mol Cell Biol 14:4342-4349

22. Wakao H, Gouilleux F, Groner B 1994 Mammary gland tactor (MGF) is a novel member of the cytokine regulated transcription factor gene family and confers the PRL response. EMBO J 13:21822191

23. Hou J, Schindler U, Henzel WJ, Ho TC, Brasseur M, McKnight SL 1994 An interleukin-4 induced transcription factor: IL-4 Stat. Science 265:1701-1706

24. Mui ALF, Wakao H, O'Farrell AM, Harada N, Miyajima A 1995 Interleukin-3, granulocyte-macrophage colony stimulating factor and interleukin-5 transduce signals through two STAT5 homologues. EMBO J 14:1166-1175

25. Liu X, Gouilleux F, Groner B, Hennighausen L, Cloning and expression of Stat 5 and a novel homologue (Stat 5 b) involved in prolactin signal transduction in mouse mammary tissue. Proc Natl Acad Sci USA, in press

26. Azam M, Erdjument-Bromage $H$, Kreider BL, Xia M, Quelle F, Basu R, Saris C, Tempst P, Ihle JN, Schindler C 1995 Interleukin-3 signals through multiple isoforms of Stat5. EMBO J 14:1402-1411

27. Barahmand-pour F, Meinke A, Eilers A, Gouilleux F, Groner B, Decker $\mathbf{T} 1995$ Colony-stimulating factors and interferon- $\gamma$ activate a protein related to MGF-Stat 5 to cause formation of the differentiation-induced factor in myeloid cells. FEBS Lett 360:29-33

28. Gouilleux F, Pallard C, Dusanter-Fourt I, Wakao $\mathbf{H}$, Haldosen $\mathrm{L} \Lambda$, Norstedt G, Levy D, Groner B 1995 Prolactin, growth hormone, erythropoietin and granulocyte-macrophage colony stimulating facLor induce MGF-STAT5 DNA binding activity. EMBO J 14:2005-2013

29. Pallard C, Gouilleux F, Bénit L, Cocault L, Souyri M, Levy D, Groner B, Gisselbrecht S, Dusanter-Fourt I 1995 Thrombopoietin activates a SIAI5-like factor in hematopoietic cells. EMBO J 14: $2847-2856$

30. Wood TJJ, Sliva D, Pircher T, Lobie PE, Gouilleux F, Wakao H, Gustafsson JA, Groner B, Norstedt G, Haldosén LA 1995 Mediation of growth hormone-dependent transcriptional activation by mammary gland factor-Stat5. J Biol Chem 270:9448-9453

31. Gouilleux F, Wakao H, Mundt M, Groner B 1994 Prolactin induces phosphorylation of tyr694 of Stat5(MGF), a prerequisite for DNA binding and induction of transcription. EMBO J 13:4361 4369

32. Shuai K, Stark GR, Kerr IM, Darnell JE 1993 A single phosphotyrosine residue of Stat 91 required for gene activation by interferon- $\gamma$. Science 261:1808-1812

33. Schmitt-Ney M, Doppler W, Ball RK, Groner B 1991 Beta-casein gene promoter activity is regulated by the hormone-mediated relief of transcriptional repression and a mammary-specific nuclear factor. Mol Cell Biol 11:3745-3755

34. Wakao H, Schmitt-Ney M, Groner B 1992 Mammary gland-specific nuclear factor is present in lactating rodent and bovine mammary tissue and composed of a single polypeptide of $89 \mathrm{kDa}$. J Biol Chem 267:16365-16370

35. David M, Petricoin III EF, Igarashi KI, Feldman GM, Finbloom DS, Larner AC 1994 Prolactin activates the interferon-regulated p91 transcription factor and the Jak2 kinase by tyrosine phosphorylation. Proc Natl Acad Sci USA 91:7174-7178

36. Gilmour KC, Reich NC 1994 Receptor to nucleus signaling by prolactin and interleukin-2 via activation of latent DNA-binding factors. Proc Natl Acad Sci USA 91:6850-6854

37. Goldsmith MA, Greene WC 1994 In: Thomson A (ed) The Cytokine Handbook. Paston P'ress, Norfolk, pp 57-80

38. Hatakeyama M, Tsudo M, Minamoto S, Kono T, Doi T, Miyata T, Miyasasa M, Taniguchi T 1989 Interleukin-2 receptor $\beta$ chain gene: generation of three receptor forms by cloned human $\alpha$ and $\beta$ chain cDNA's. Science 244:551-556

39. Nakamura $\mathbf{Y}$, Russell SM, Mess SA, Friedmann $\mathbf{M}_{r}$, Erdos $\mathbf{M}_{r}$ Francois C, Jacques Y, Aldenstein S, Leonard WJ 1994
Heterodimerization of the IL- 2 receptor $\beta$ - and $\gamma$-chain cytoplasmic domains is required for signaling. Nature 369:330-333

40. Kobayashi N, Kono T, Hatakeyama M, Minami Y, Miyazaki T, Perlmutter TM, Taniguchi T 1993 Functional coupling of the srcfamily protein tyrosin kinases p59fyn and p53/56lyn with the interleukin 2 receptor: implication for redundancy and pleiotropism in cytokine signal transduction. Proc Natl Acad Sci USA 90:42014205

41. Minami Y, Kono T, Yamada K, Kobayashi N, Kawahara A, Perlmutter RM, Taniguchi T 1993 Association of p56lck with IL-2 receptor $\beta$ chain is critical for the IL-2 induced activation of p56lck. EMBO J 12:759-768

42. Miyazaki T, Kawahara A, Fujii H, Nakagawa Y, Minami Y, Liu ZJ, Oishi I, Silvennoinen O, Witthuhn BA, Ihle JN, Taniguchi T 1994 Functional activation of Jak1 and Jak3 by selective association with IL-2 receptor subunits. Science 266:1045-1047

43. Russell SA, Johnston JA, Noguchi M, Kawamura M, Bacon CM, Friedmann M, Berg M, McVicar DW, Witthuhn BA, Silvenoinnen O, Goldman AS, Schmalstieg FC, Ihle JN, O'Shea JJ, Leonard WJ 1994 Interaction of IL-2R $\beta$ and $\gamma$ chains with Jak1 and Jak3: implications for XSCID and XCID. Science 266:1042-1045

44. Beadling C, Gushin D, Witthuhn BA, Ziemiecki A, Ihle JN, Kerr IM, Cantrell DA 1994 Activation of Jak kinases and Stats proteins by interleukin-2 and interferon $\alpha$, but not the T cell antigen receptor, in human T Iymphocytes. EMBO J 13:5605-5615

45. Fujii H, Nakagawa Y, Schindler U, Kawahara A, Gouilleux F, Groner B, Ihle JN, Minami Y, Mijazaki T, Taniguchi T 1995 Activation of Stat 5 by IL-2 requires a carboxy terminal region of the IL-2 receptor $\beta$ chain but is dispensable for the proliferative signal transmission. Proc Natl Acad Sci USA 92:5482-5486

46. Rayhel EJ, Fields TJ, Albright JW, Diamantstein T, Hughes JP 1988 Interleukin 2 and a lactogen regulates proliferation and protein phosphorylation in Nb2 cells. Biochem J 249:333-338

47. Yu-Lee LY, Hrachovy JA, Stevens AM, Schwarz LA 1990 Interferon regulatory factor- 1 is an immediate early gene under transcriptional regulation by prolactin in Nb2 T cells. Mol Cell Biol 10:3087-3094

48. Standke G, Meyer V, Groner B 1994 Mammary gland factor activated by prolactin in mammary epithelial cells and acute phase response factor activated by IL-6 in liver cells share DNA binding and transactivation potential. Mol Endocrinol 8:469-477

49. Pine R, Canova A, Schindler C 1994 Tyrosine phosphorylated p91 binds to a single element in the ISGF2/IRF-1 promoter to mediate induction by IFN- $\alpha$ and IFN- $\gamma$, and is likely to autoregulate the $\mathrm{p} 91$ gene. EMBO J 13:158-167

50. Ali S, Pellegrini I, Kelly PA 1991 A prolactin-dependent immune cell line $(\mathrm{Nb2})$ expresses a mutant form of prolactin receptor. J Biol Chem 266:20110-20117

51. Seidel MH, Milocco LH, Lamb P, Darnell JE, Stein RB, Rosen J 1995 Spacing of palindromic half sites as a determinant of selective STAT (signal transducers and activators of transcription) DNA binding and transcriptional activity. Proc Natl Acad Sci USA 92:30413045

52. Wakao H, Harada N, Kitamura T, Mui ALF, Mijajima A 1995 Interleukin-2 and erythropoietin activate Stat $5 / \mathrm{MGF}$ via distinct pathways. EMBO J 14:2527-2535

53. Schwarz LA, Stevens AM, Hrachovy JA, Yu-Lee LY 1992 Interferon regulatory factor- 1 is inducible by prolactin, interleukin-2 and concanavalin A in T cells. Mol Cell Endocrinol 86:103-110

54. Harroch S, Revel M, Chebath J 1994 Induction by interleukin-6 of interferon regulatory factor 1 (IRF-1) gene expression through the palindromic interferon response element pIRE and cell type-dependent control of IRF-1 binding to DNA. EMBO J 13:1942-1949

55. Sadowski HB, Shuai K, Darnell Jr J, Gilman MZ 1993 A common nuclear signal transduction pathway activated by growth factor and cytokine receptors. Science 261:1739-1744 